\title{
Industrial Production and Capacity Utilization: The 2001 Annual Revision
}

Carol Corrado, Charles Gilbert, and Norman Morin, of the Board's Division of Research and Statistics, prepared this article. Kristen Hamden provided research assistance.

In late 2001, the Board of Governors of the Federal Reserve System published the annual revision of its index of industrial production (IP) and the related measures of capacity and capacity utilization for the period January 1992 through October 2001 (chart 1). Measured from fourth quarter to fourth quarter, industrial output and capacity are reported to have increased at a slower rate in 1999 and 2000 than previously reported, and the revision places the decline in IP in 2001 at an annual rate of 6.0 percent. ${ }^{\perp}$ The estimated rate of increase in capacity in 2001 was lowered 0.7 percentage point, to 1.7 percent.

Despite the downward revision to IP in 1999 and 2000 , the general contour is the same as that in the

NoтE. Charles Gilbert directed the 2001 annual revision and prepared the revised estimates of industrial production; Norman Morin prepared the revised measures of capacity and capacity utilization. Other contributors to the revision and this article were William Cleveland, Mark Doms, Marie DeGregorio, Gloria Fennell, Kristen Hamden, Susan Polatz, and Dixon Tranum.

1. Data referred to in the text and shown in table 1 are based on IP and utilization rates as published on January 16, 2002. Statements referring to previously reported estimates refer to data published on November 16, 2001. earlier estimates. After having picked up in the second half of 1999 and having posted rapid gains in the first half of 2000, industrial output slowed noticeably at midyear. According to the revised data, however, industrial output in the second half of 2000 was weaker than previously estimated, and the peak in IP occurred in June 2000 instead of August 2000. The cumulative decline in IP since the June peak is 7.0 percent (table 1). ${ }^{2}$

The rate of industrial capacity utilization (the ratio of production to capacity) as of the third quarter of 2001 was little changed by the revision; at 74.6 percent in the fourth quarter of 2001 , the rate is 4 percentage points below the nadir of the 1990-91 recession but 3 percentage points above that of the 1982 recession. ${ }^{3}$ For the fourth quarter of 2000 , capacity utilization was revised down 0.6 percentage point, to 80.7 percent; a downward revision to the operating rate in manufacturing of 1.2 percentage points was partly offset by an upward revisions to the operating rates in mining and utilities.

2. The revised data show consecutive declines in monthly IP for the nine months ending June 2001, a 0.1 percent increase in July 2001 , and decreases for the five months ending December 2001; the earlier data showed declines in monthly IP in every month from October 2000 to October 2001.

3. These comparisons use quarterly average data.

1. Industrial production, capacity, and utilization

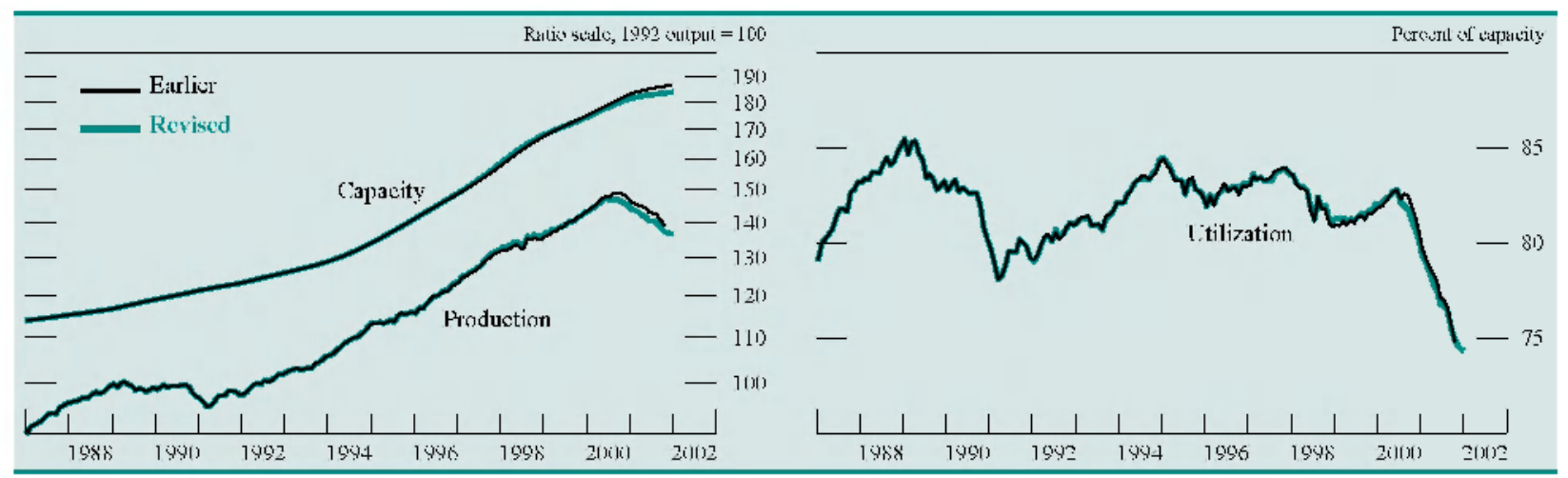

Note. The production indexes and utilization rates are seasonally adjusted. All the revised measures extend through December 2001; the earlier measures extend through October 2001 
The updated measures reflect the incorporation of newly available, more-comprehensive source data and the introduction of improved methods for compiling a few series. The new source data are for recent years, primarily 1999 forward, and the modified methods affect the indexes from 1992 forward.

The statistical revisions to the IP index were derived principally from the inclusion of information contained in annual reports issued by the U.S. Census Bureau - the 1999 Annual Survey of Manufactures and selected 2000 Current Industrial Reports. Annual data from the U.S. Geological Survey (USGS) on minerals (except fuels) were also introduced; revised data for 1999 and some new data for 2000 were available. In addition, the new monthly production estimates for 2000 and 2001 reflect updated seasonal factors and the inclusion of monthly source data that became available (or were revised) after the closing of the regular four-month reporting window.

The capacity indexes and capacity utilization rates incorporate the revised production indexes, results from the Census Bureau's 2000 Survey of Plant Capacity for the fourth quarter of the year, and newly available 2000 data on industrial capacity from the USGS, the Energy Information Administration (EIA) of the U.S. Department of Energy, and other organizations. In addition, the relationships used to estimate the current change in manufacturing capacity reflect the inclusion of the Census data on capital spending by industry for 1999 and indicators of the rate of change in manufacturing capital spending in 2000 and 2001.

The revised indexes of industrial production and capacity also reflect the updating of the value-added weights used in aggregating the individual indexes to the major industry and market group subtotals and to total industry. The industry groups in IP and capacity continue to be based on the 1987 Standard Industrial Classification (SIC); in the 2002 revision, the industrial production and capacity utilization data will be constructed and grouped according to the North American Industry Classification System (NAICS).

Beginning with this revision, the capacity index for the extraction of natural gas is based on newly available estimates from the EIA; the new data substantially lower the estimate of the industry's capacity for the 1995-99 period. The new EIA figures are designed to better reflect the ability of producing wells to deliver gas into the gathering and pipeline system; the previous EIA figures measured capacity at the wellhead only. The revision also incorporates new source data for another capacity series (silver); refinements to the methods used to compile two monthly production series (construction machinery and original equipment motor vehicle parts); and new methods and new source data to derive the value-

1. Revised rates of change in industrial production and capacity and the revised rate of capacity utilization, 1998-2001

\begin{tabular}{|c|c|c|c|c|c|c|c|c|c|c|c|}
\hline \multirow[b]{2}{*}{ Item } & \multirow{2}{*}{$\begin{array}{c}2000 \\
\text { pro- } \\
\text { portion }\end{array}$} & \multicolumn{5}{|c|}{$\begin{array}{l}\text { Revis }=d \text { rate of change } \\
\text { (percent) }\end{array}$} & \multicolumn{5}{|c|}{$\begin{array}{l}\text { Diflerence between revised and previous } \\
\text { (putcuntage points;) }\end{array}$} \\
\hline & & $\begin{array}{l}1998- \\
2001 \\
\text { avg. }\end{array}$ & 1998 & 1999 & 2000 & 2001 & $\begin{array}{c}1998- \\
2001 \\
\text { avg. }\end{array}$ & 1998 & 1999 & 2000 & 2001 \\
\hline \multicolumn{12}{|l|}{ Production } \\
\hline Total industry. & 100.0 & 1.7 & 3.5 & 4.3 & 2.6 & -6.0 & -.5 & .3 & -.7 & -1.6 & -.1 \\
\hline Manufacturing ............... & 86.5 & 1.8 & 4.3 & 4.8 & 2.3 & -6.3 & -.6 & .3 & -8 & -1.9 & 1 \\
\hline industries ............. & 78.3 & -.5 & 1.4 & 1.9 & -1.3 & -5.3 & -.2 & .2 & -.4 & -.7 & .7 \\
\hline Selected high-tech industries & 8.2 & 22.5 & 35.8 & 34.0 & 39.5 & -15.9 & -7.3 & -1.4 & -6.6 & -15.8 & -5.1 \\
\hline Mining and utilities ........... & 13.5 & .5 & -2.7 & 1.3 & 4.2 & -3.8 & .3 & .5 & .2 & 4 & -1.8 \\
\hline \multicolumn{12}{|l|}{ Capacity } \\
\hline Total industry & 100.0 & 4.0 & 6.4 & 3.9 & 4.0 & 1.7 & -.5 & -.1 & -.7 & -5 & -7 \\
\hline Manufacturing & 88.0 & 4.5 & 7.2 & 4.5 & 4.7 & 1.6 & -.5 & -.1 & -6 & -3 & -1.0 \\
\hline $\begin{array}{l}\text { Excluding selected high-tech } \\
\text { industries }\end{array}$ & 794 & 10 & 44 & & 10 & 3 & & -1 & 0 & & \\
\hline Selected high-tech industries & 8.7 & $\begin{array}{r}1.9 \\
30.3\end{array}$ & $\begin{array}{r}4.4 \\
36.6\end{array}$ & 28.6 & $\begin{array}{r}1.0 \\
42.9\end{array}$ & 12.9 & $\begin{array}{r}-.2 \\
-6.3\end{array}$ & $\begin{array}{l}-.1 \\
-2.8\end{array}$ & -9.2 & $\begin{array}{r}-3 \\
-4.7\end{array}$ & $\begin{array}{r}-.3 \\
-8.6\end{array}$ \\
\hline Mining and utilities .......... & 12.0 & 1.0 & -2 & .5 & 8 & 3.1 & .0 & -8 & -.3 & -4 & 1.3 \\
\hline \multicolumn{12}{|l|}{$\begin{array}{l}\text { Capacity utilization } \\
\text { (percent, end of period) }\end{array}$} \\
\hline Total industry. & 100.0 & 80.1 & 81.5 & 81.8 & 80.7 & 74.6 & -.1 & .2 & .2 & -.6 & -.2 \\
\hline Manufacturing & 88.0 & 78.9 & 80.7 & 81.0 & 79.1 & 72.9 & -.3 & .2 & .1 & -1.2 & -.4 \\
\hline $\begin{array}{c}\text { Excluding selected high-tech } \\
\text { industries }\end{array}$ & 79.4 & 79.1 & 80.8 & 80.7 & 78.9 & 74.5 & -2 & .1 & -2 & -6 & .1 \\
\hline Selected high-tech industries & 8.7 & 78.1 & 79.8 & 83.2 & 81.2 & 60.5 & -.5 & .7 & 2.4 & -3.9 & -2.3 \\
\hline Mining and utilities ........... & 12.0 & 89.2 & 88.1 & 88.8 & 91.8 & 85.7 & 1.4 & 1.3 & 1.7 & 2.4 & .3 \\
\hline
\end{tabular}

NoTE. The 1998-2001 average rate of change is calculated as the average annual percent change in the seasonally adjusted index from the fourth quarter of 1997 to the fourth quarter of 2001 . Rates for years are calculated from the fourth quarter of the previous year to the fourth quarter of the year specified. The capacity utilization rates for years are for the last quarter of the year.

The difference between revised and previous rates of change for IP for 2001 is

calculated for the period 1997:Q4 to 2001:Q3. The difference in capacity utilization for 2001 refers to 2001:Q3 and the difference for 1998-2001 refers to the period ending 2001:Q3.

High-tech industries include the manufacturers of semiconductors and related devices, computers and computer peripherals, and communications equipment. 
added weights for the IP and capacity series for electric utilities. The rates of change in the new weights were applied to the old 1992 weight to derive a new series of annual weights ("best-change" method) and result in slightly larger value-added proportions for the electric utility industry.

\section{SUMMARY OF THE REVISION}

For the third quarter of 2001, the revision places the production index at 139.6 percent of output in 1992 and the capacity index at 183.2 percent of output in 1992 (appendix table 1); both indexes are lower than reported previously (chart 1). As noted earlier, the capacity utilization rate was little changed for the third quarter of 2001.

Appendix tables 2, 3, and 4 show new data for monthly manufacturing IP and capacity utilization as well as the results for total and manufacturing industries, excluding selected high-technology industries. Tables 5 and 6 show the revised rates of change of industrial production for market groups, industry groups, special aggregates, and selected detail for the years 1997 through 2001 (fourth quarter to fourth quarter); tables 7 and 8 show the revised figures for capacity utilization and capacity. For production and capacity, the tables also show the difference between the revised and earlier rates of change (third quarter used for 2001). For capacity utilization, the tables show the difference between the revised and previous rates for the final quarter of the year.

\section{Industrial production}

The revision lowered the rate of increase in industrial output 0.7 percentage point for 1999 and 1.6 percentage points for 2000 (measured from the fourth quarter of the preceding year to the fourth quarter of the year indicated); the increase in industrial production was raised slightly for 1997 and 1998.

The somewhat faster increase in IP now shown for 1997 and 1998 reflects both the incorporation of: recently issued revisions to the annual Census data and the introduction of refinements and revisions to the price deflators used to construct the annual indexes that determine the trend in each industrial production series from one year to the next. ${ }^{+}$

4. The general methods used to measure individual IP series were reviewed in an article published in the March 2001 issue of the Federal Reserve Bulletin (www.federalreserve.gov/pubs/bulletin/ 2001/0301send.pdf)
For most two-digit manufacturing industries, the new annual reports issued by the Census Bureau implied only small changes to previously published IP figures for 1999. The output indexes for the transportation equipment industry, the apparel and products industry, and the rubber and plastics industry were revised up. However, new data for the computer industry, mainly for printers and other peripheral equipment, implied a weaker gain in output for the industrial machinery and equipment group. The output of that industry was also lowered in 2000 because of the inclusion of available data from the Current Industrial Reports. Nonetheless, on balance, the revised data still indicate that the production of industrial machinery and equipment increased at a robust rate in both years.

The revision now places the rise in the production index for the output of high-technology industriescomputers and office equipment (SIC 357), semiconductors and related devices (SIC 3672-9), and communications equipment (SIC 366) - at about 40 percent in 2000 . The previously published estimate was appreciably stronger; the new estimates show less-rapid gains in the output of semiconductors, computers, and peripherals. The downward revisions to the indexes for semiconductor output reflect the incorporation of data from the 2000 Current Industrial Report and more-comprehensive information on prices.

Excluding high-technology industries, the revised IP series show more-pronounced weakness, mainly in manufacturing, in the second half of 2000 . The change reflects the updating of seasonal factors and the inclusion of revisions to monthly source data. The more-pronounced weakness appears in the durable goods manufacturing industries, especially the industrial machinery, motor vehicle parts, instruments, furniture, and stone, clay, and glass products industries.

Among major market groups, the revised production indexes for consumer goods and for construction supplies showed, on balance, little change for 2000 and 2001. The revised indexes for business equipment and for industrial materials showed slower gains in 2000 and little change in the decline for 2001.

The revised position of the peak in 2000 in overall industrial production reflects reductions in the rates of change between June 2000 and August 2000 for several industries. The selected high-technology aggregate is a major contributor to the change in the peak; new data suggest that output in 2000 was lower than previously estimated, and based on revised highfrequency source data, production was revised down more sharply in the second half of 2000 than in the first half: In addition, both new data on cigarette production and updated methods for estimating the 
output of motor vehicle parts contributed to the dip into negative territory of the rate of change in IP between June 2000 and August 2000.

Over history, the initial estimates of industrial production have tended to reliably indicate the turning points in IP (with all of its source data incorporated). For the four previous recessions, the initial estimates identified the first month of decline in IP correctly or one month early. For three of the four previous recessions, they identified the first month of recovery correctly or one month early. For the fourth recession, despite showing a significant slowing of declines around the currently estimated turning point, the initial estimates of IP pegged the beginning of the recovery two months later than is now shown.

\section{Capacity}

Manufacturing capacity in 2001 is estimated to have risen 1.6 percent, more than 1 percentage point lower than previously published. On average, manufacturing capacity increased 4.6 percent per year in 1999 and 2000 (previously estimated at about 5 percent) and, on average, expanded 6 percent per year from 1994 through 1998 (a number virtually unchanged from the previous estimates). The rapid gains in capacity during the second half of the 1990s were concentrated in industries that produce hightechnology goods and devices. Given the downward revision to output in these industries, the pace of capacity expansion was also revised down; nonetheless, from 1994 through 2000 it still averaged nearly 40 percent per year. The relatively slow expansion of capacity in these industries in 2001, now estimated at 12.9 percent, was in large part the result of a downshift in capital spending by semiconductor manufacturers. Outside the selected high-technology industries, investment spending for 2001 is estimated to have fallen 6 percent, and plant capacity is estimated to have edged up 0.3 percent, down from the 2 percent pace in 1999 and the 3.2 percent annual average for 1994 through 1998.

Capacity in mining was revised down noticeably for the 1995-2000 period but was revised up substantially for 2001 . The changes were primarily the result of incorporating new EIA measures for the capability to extract natural gas; in value-added terms, natural gas extraction is about 30 percent of mining output. According to the revised data, from 1995 through 1998, capacity at mines increased a scant 0.1 percent per year, and in 1999 and 2000, it declined about 2 percent per year. For 2001 , however, mining capacity is estimated to have increased 0.4 percent.
Capacity at electric and gas utilities increased a bit more slowly from 1997 through 2000 than previously reported. The North American Electric Reliability Council reduced its estimate of generating capacity for 2000 but sharply increased the estimate for 2001; as a result, the rise in capacity at utilities for 2001 was revised up more than 1 percentage point, to 5.2 percent. In both the previous and the revised data, the rate of expansion of utility capacity for 2001 is the largest since 1974, a surge reflecting the response of producers to the significant shortfall in generating capacity last winter.

\section{Capacity Utilization}

The Survey of Plant Capacity indicated that the factory operating rate was lower in the fourth quarter of 2000 than previously estimated. The revised utilization rate for manufacturing was 79.1 percent in the final quarter of 2000,1 percentage point lower than reported earlier.

Capacity utilization in manufacturing reached 81.7 percent in the middle of $2000,0.6$ percentage point above its long-term (1967-2000) average. The factory operating rate had climbed to 83 percent in 1997, before the onset of economic turmoil in Asia, but dropped back more than 2 percentage points by the end of 1998. From the middle of 2000 through the fourth quarter of 2001, the utilization of manufacturing capacity plummeted almost 9 percentage points.

Among manufacturing industries in the fourth quarter of 2001, the utilization rates for primary processors were nearly the same as those for advanced processors. Since the middle of 2000 , the decline in the rate for primary-processing industriesabout 12 percentage points-has been especially sharp. Primary processors were operating at relàtively elevated rates in the second quarter of 2000 . The rates for primary metals; semiconductors; stone, clay, and glass products; petroleum products; and motor vehicle parts were above their long-term averages. By the fourth quarter of 2001 , the only primaryprocessing industry that was operating at rates above its long-term average was petroleum and products. Among advanced processors, only the producers of light trucks, ships and boats, and chemical products were operating at above-average rates.

Capacity utilization in mining was revised up to 90.7 percent in the third quarter of 2001 and then declined to 88.4 percent in the fourth quarter, still somewhat higher than its long-term average of 87.6 percent. The utilization rate for electric and gas utilities in the third quarter of 2001 was little changed 
by the revision, but the rates in 1998,1999 , and 2000 increased.

\section{TECHNICAL ASPECTS OF THE REVISION.}

As noted earlier, the annual revision incorporated more-comprehensive annual data on industry output, utilization, value added, and capital spending for 1999 and 2000, along with an update of all seasonal factors and monthly data on production, productionworker hours, and electric power use. In addition, the capital input measures used in the construction of capacity indexes incorporate more-recent data for overall business investment and prices from the Bureau of Economic Analysis. ${ }^{5}$

Previously issued annual data on output and prices for 1997 and 1998 that were slightly revised by the original source were also included.

The Census Bureau reported its new 1999 and 2000 data on industry output and capacity utilization, as well as its revisions to 1997 and 1998 data, on the new North American Industrial Classification System (NAICS). Before being included in the IP and capacity indexes, which continue to be based on the 1987 Standard Industrial Classification (SIC), the data were recategorized by the Federal Reserve according to the SIC system.

In the 2002 revision, the industrial production and capacity utilization data will be derived according to NAICS; data from at least 1977 forward will be subject to revision; and the indexes will be rebased, with 1997 equal to 100 . The new NAICS production data will be derived from annual output measures constructed by reclassifying the establishments in historical Censuses of Manufactures and Mineral Industries according to NAICS categories; annual output indexes constructed in this way maximize the reliability and historical consistency of the IP industry detail.

\section{Revised Monthly Data}

The product data that are used to measure the monthly movements of many IP indexes were

\footnotetext{
5. The general methods used to measure individual capacity series were summarized in the March 2001 issue of the Federal Reserve Bulletin. A fuller description of the models used to develop the Federal Reserve's capacity estimates were reported in the March 2000 issue of the Bulletin (www.federalreserve.gov/pubs/bulletin/2000/ 0300 secnd.pdf).
}

updated to capture data that became available after the closing of the regular four-month reporting window. For example, monthly data from the U.S. Department of the Treasury on the production of alcoholic beverages and cigarettes may be unavailable initially but available for inclusion in the annual revision.

The input measures were also updated to incorporate revised data on monthly production-worker hours (based on the Bureau of Labor Statistics [BLS] benchmark of employment to March 2000 comprehensive measures) and on monthly electric power use since 1997. Besides benchmarking data on production-worker hours to March 2000 comprehensive measures, the BLS also incorporated data derived from new sampling procedures from 1999 forward. The new estimates reduced the change in production-worker hours at manufacturers in the second half of 2000 , with the bulk of the reduction in industries in which the data on production-worker hours are used as the monthly production indicator in IP.

Seasonal factors for all series were re-estimated using data that extend into 2001. Factors for production-worker hours, which adjust for timing, holiday, and monthly seasonal patterns, were updated with data through October 2001. Factors for the electric power series, which are developed using multivariate methods, were re-estimated using data through May 2001. The updated factors for the physical product series, which include adjustments for holiday and workday patterns, used data through at least June 2001. Seasonal factors for unit motor vehicle assemblies were updated with data through September 2001; they are on the Board's web site at www.federalreserve.gov/releases/g 17/mvsf.htm.

\section{Weights for Aggregation}

The weights for the aggregation of IP indexes and capacity utilization rates are derived from annual estimates of industry value added. For manufacturing, the Census Bureau provides such data annually; for mining, quinquennial figures are provided. For the electric and gas utility industries, the Federal Reserve derives estimates of value added from annual revenue and expense data issued by other organizations. Estimates of industry value added were updated with annual data through 1999, and the weights for aggregation (unit value added) were estimated using the most recent data on producer prices. Appendix table 9 reports the annual value-added 
proportions incorporated in the IP index from 1994 forward.

Beginning with this revision, the methods and data used to obtain estimates of value added in the electric utility industry have been improved. A change was necessary for several reasons. First, many of the data that had been used to compute value added were contained in an EIA publication that has been discontinued. Second, the EIA data on "utilities" include regulated entities only, and data covering all producers of electric power (that is, including the unregulated power generators) are required to avoid a severe understatement of the value added by the entire industry in 2000. Finally, a review of the earlier methods suggested value added was understated for the period preceding the deregulation of the industry.

The Federal Reserve's new estimates of value added for the electric utility industry were constructed according to the Census definition of value added, that is, industry revenue minus the cost of purchased material inputs. Data on industry revenue (including all establishments that distribute power to final users) were obtained from Statistical Yearbooks issued by the Edison Electric Institute; these data were combined with EIA measures of fuel costs to obtain an estimate of Census value added. The new figures were applied on a best-change basis for the period from 1992 forward; the 2002 revision will introduce refined results as well as revised figures for earlier years.

\section{Changes to Individual Series}

With this revision, the capacity series for natural gas extraction (part of SIC 13) incorporates new estimates developed by the EIA; the new estimates are substantially lower than the agency's previous figures that were used to derive the capacity for natural gas extraction. The new figures are designed to better reflect the ability of producing wells to deliver gas into the gathering and pipeline system, whereas previous EIA figures measured capacity at the wellhead only.

The source data for one other capacity series has changed. The index for silver capacity is now based on data from the USGS; previously it was derived using a trend-through-peak method.

The monthly production indicators for construction machinery and original equipment motor vehicle parts were refined. The weights used to combine the available product data for construction machinery were updated. The indicator for motor vehicle parts is
2. U.S. LAN equipment, 1992-2001

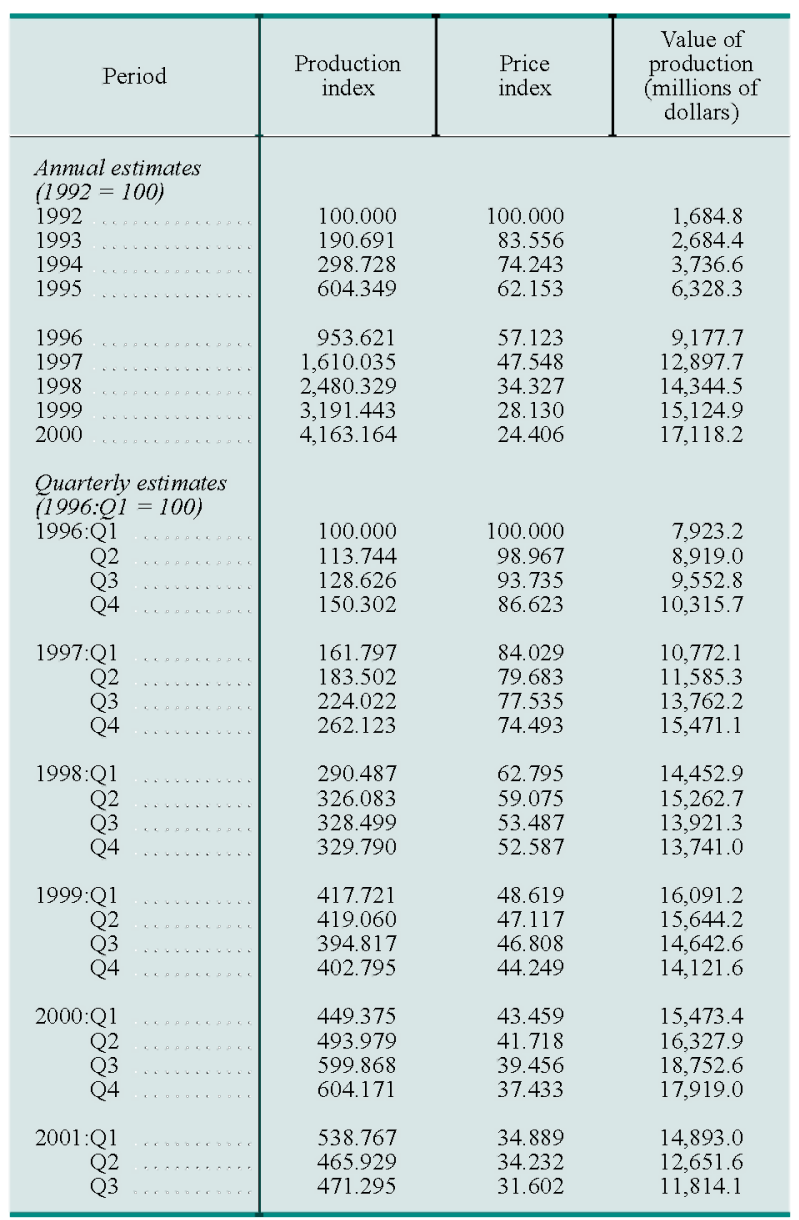

now developed from monthly product data (engines, brakes, axles, and transmissions), production-worker hours, and motor vehicle assemblies; previously, the series was derived from the product data only.

The annual estimates of motor vehicle repair parts were also improved; their derivation now includes information on the average age of the motor vehicle fleet.

\section{LAN Equipment}

The 2000 revision introduced a new IP series for the production of local area network (LAN) equipment (routers, switches, and hubs). The new series is not published in the monthly statistical release, but it is included in the broader IP aggregate for communications equipment and updated on an ongoing basis (see the March 2001 Bulletin article). Table 2 shows updates of the results for LAN equipment originally issued a year ago. 


\section{APPENDIX A: SUMMARY TABLES BASED ON THE G.17 RELEASE, JANUARY 16, 2002}

A.1. Revised data for industrial production, capacity, and utilization for total industry

Seasonally adjusted data except as noted

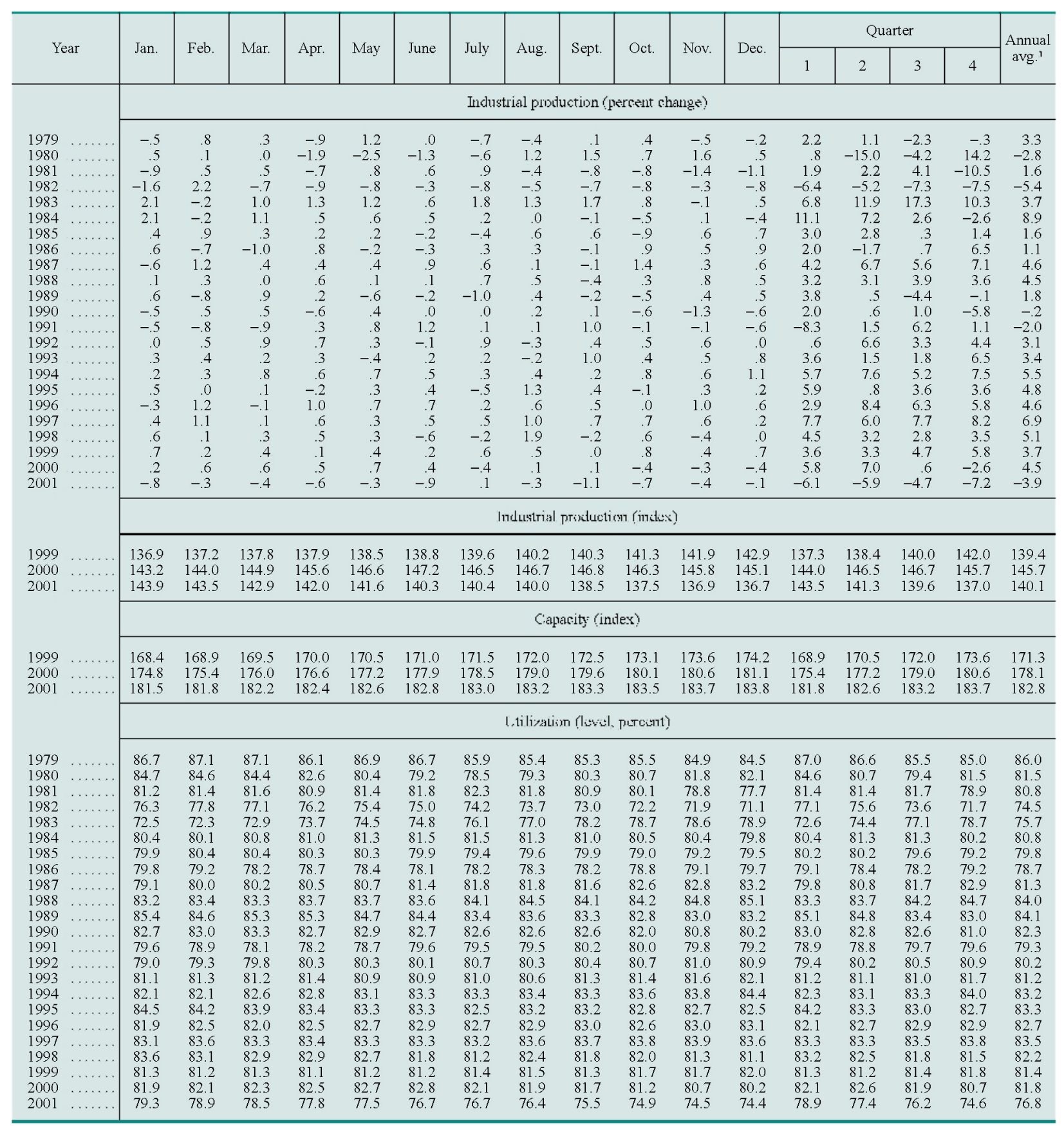

Note. Monthly percent change figures show change from the previous

Estimates from October 2001 through December 2001 are subject to further month; quarterly figures show the change from the previous quarter at a

1 Annual averages of industrial production are calculated from indexes that compound annual rate of growth.
as percentages of: output in 1992. are not seasonally adjusted. 
A.2. Revised data for industrial production, capacity, and utilization for manufacturing industries Seasonally adjusted data except as noted

\begin{tabular}{|c|c|c|c|c|c|c|c|c|c|c|c|c|c|c|c|c|c|}
\hline \multirow{2}{*}{ Year } & \multirow{2}{*}{ Jan. } & \multirow{2}{*}{ Feb. } & \multirow{2}{*}{ Mar. } & \multirow{2}{*}{ Apr. } & \multirow{2}{*}{ May } & \multirow{2}{*}{ June } & \multirow{2}{*}{ July } & \multirow{2}{*}{ Aug } & \multirow{2}{*}{ Sept. } & \multirow{2}{*}{ Oct. } & & & & $\mathrm{Qu}$ & & & \\
\hline & & & & & & & & & & & Nov. & Dec. & 1 & 2 & 3 & 4 & avg.' \\
\hline & & & & & & & Indus & ial prov & detion? & ereent $\mathrm{c}$ & ange) & & & & & & \\
\hline 1979 & -.3 & .7 & .4 & -1.5 & 1.5 & .1 & -.5 & -9 & .0 & 5 & -.7 & -.1 & 3.4 & .3 & -2.4 & -1.5 & 3.6 \\
\hline 1980 & .2 & 3 & -4 & -2.1 & -3.1 & -1.5 & -7 & 1.7 & 1.5 & 11 & 1.7 & 3 & -4 & -17.7 & -4.7 & 168 & -3.9 \\
\hline 1981 & -.6 & 6 & 3 & .2 & .7 & -1 & 6 & -8 & -8 & -11 & -1.6 & -1.6 & 2.5 & 4.2 & -1 & -13.1 & 1.6 \\
\hline 1982 & -2.0 & 2.9 & -.7 & -.9 & -.4 & .0 & -.8 & -.5 & -.5 & -12 & -.3 & -.7 & -7.6 & -2.7 & -5.6 & -8.0 & -5.9 \\
\hline 1983 & 2.5 & .4 & 1.4 & 1.1 & 1.4 & 8 & 1.5 & 1.1 & 2.2 & 6 & .3 & -1 & 11.5 & 14.7 & 17.1 & 11.2 & 5.7 \\
\hline 1984 & 2.5 & .6 & .7 & .5 & 4 & .7 & .3 & .1 & -2 & 0 & .1 & -.3 & 13.2 & 6.6 & 3.4 & -4 & 9.9 \\
\hline 1985 & .1 & .6 & .7 & .2 & .5 & -3 & -.4 & 9 & .4 & -8 & 1.1 & -.1 & 2.1 & 4.2 & 1.1 & 1.6 & 2.3 \\
\hline 1986 & 1.5 & -.5 & -.9 & 1.4 & -.1 & -3 & .3 & 6 & .0 & 8 & 4 & 1.2 & 4.5 & 1.7 & 1.7 & 6.7 & 2.8 \\
\hline 1987 & -8 & 1.6 & .2 & 5 & 3 & 1.0 & .7 & -2 & .1 & 13 & .5 & 6 & 5.0 & 7.0 & 5.5 & 7.6 & 5.3 \\
\hline 1988 & -.2 & 4 & -1 & 1.0 & -.1 & .0 & .7 & 3 & .2 & 2 & 9 & .6 & 2.3 & 4.1 & 3.7 & 5.2 & 4.7 \\
\hline 1989 & .9 & -1.2 & .8 & .1 & -.7 & .0 & -1.1 & 3 & -.3 & -6 & 4 & .1 & 4.3 & -7 & -4.5 & -1.4 & 1.9 \\
\hline 1990 & -.2 & .9 & .3 & -.8 & 4 & -1 & .0 & 3 & -1 & -6 & -1.3 & -.6 & 2.9 & -.1 & .8 & -6.3 & -.5 \\
\hline 1991 & -.9 & -.7 & -1.1 & .3 & .7 & 1.4 & .2 & 2 & 1.1 & -1 & -.2 & -.5 & -9.7 & 1.2 & 7.8 & 1.7 & -2.4 \\
\hline 1992 & .1 & .7 & 1.0 & .6 & 4 & .0 & .9 & -3 & .3 & 5 & .6 & -.1 & 2.0 & 7.4 & 4.1 & 3.7 & 4.0 \\
\hline 1993 & .7 & .2 & .2 & .5 & -.3 & .0 & .2 & -3 & 1.1 & 4 & .5 & .9 & 4.2 & 2.1 & 1.3 & 6.9 & 3.7 \\
\hline 1994 & .1 & .4 & 1.1 & .8 & .8 & 3 & .5 & 6 & 3 & 9 & .8 & 1.1 & 5.9 & 9.4 & 6.0 & 9.0 & 6.1 \\
\hline 1995 & .6 & -.1 & .2 & -.3 & .1 & .5 & -.7 & 1.2 & .7 & 0 & .1 & .1 & 6.4 & 4 & 3.0 & 4.2 & 5.3 \\
\hline 1996 & -.3 & 1.2 & -.2 & 1.2 & .8 & 9 & .6 & 6 & 6 & 0 & 1.0 & .7 & 2.4 & 9.2 & 8.4 & 6.2 & 4.9 \\
\hline 1997 & .4 & 1.2 & .3 & .5 & .4 & .7 & .4 & 1.3 & .6 & 6 & .7 & .3 & 8.8 & 6.8 & 8.9 & 8.7 & 7.9 \\
\hline 1998 & .9 & .0 & .2 & .7 & .2 & -.7 & -.2 & 2.3 & -.2 & 8 & -.2 & .2 & 6.0 & 3.0 & 3.2 & 5.2 & 5.9 \\
\hline 1999 & 6 & 4 & 2 & 2 & 6 & 1 & 4 & 8 & 0 & 8 & 6 & 6 & 3.9 & 3.6 & 4.8 & 6.9 & 4.2 \\
\hline 2000 & .3 & .5 & 9 & .3 & .7 & .5 & -.4 & -1 & 1 & -5 & -.5 & -.7 & 6.3 & 7.1 & 4 & -4.0 & 4.8 \\
\hline 2001 & -.8 & -.3 & -.4 & -.8 & -.2 & -1.0 & .2 & -.5 & -1.1 & -7 & -.2 & -.1 & -7.1 & -6.2 & -4.9 & -7.1 & -4.5 \\
\hline & & & & & & & & lustrial & rixducti & 1 ? imatis & & & & & & & \\
\hline 1999 & 141.8 & 142.4 & 142.7 & 143.0 & 143.8 & 143.9 & 144.4 & 145.6 & 145.7 & 146.8 & 147.7 & 148.6 & 142.3 & 143.6 & 145.2 & 147.7 & 144.7 \\
\hline 2000 & 149.0 & 149.8 & 151.1 & 151.6 & 152.6 & 153.3 & 152.7 & 152.6 & 152.8 & 152.0 & 151.2 & 150.1 & 149.9 & 152.5 & 152.7 & 151.1 & 151.6 \\
\hline 2001 & 148.9 & 148.4 & 147.9 & 146.7 & 146.4 & 145.0 & 145.2 & 144.5 & 142.9 & 141.8 & 141.5 & 141.3 & 148.4 & 146.0 & 144.2 & 141.6 & 144.8 \\
\hline & & & & & & & & Cap & acity (in & ex) & & & & & & & \\
\hline 1999 & 176.1 & 176.8 & 177.4 & 178.0 & 178.6 & 179.2 & 179.8 & 180.4 & 181.1 & 181.7 & 182.4 & 183.1 & 176.8 & 178.6 & 180.4 & 182.4 & 179.5 \\
\hline 2000 & 183.8 & 184.6 & 185.4 & 186.1 & 186.9 & 187.7 & 188.4 & 189.1 & 189.8 & 190.4 & 191.0 & 191.5 & 184.6 & 186.9 & 189.1 & 191.0 & 187.9 \\
\hline 2001 & 192.0 & 192.4 & 192.7 & 193.0 & 193.2 & 193.4 & 193.5 & 193.6 & 193.8 & 193.9 & 194.1 & 194.2 & 192.3 & 193.2 & 193.6 & 194.1 & 193.3 \\
\hline & & & & & & & & tilizati & n (level & pereent & & & & & & & \\
\hline 1979 & 86.4 & 86.7 & 86.9 & 85.3 & 86.4 & 86.3 & 85.6 & 84.5 & 84.3 & 84.5 & 83.6 & 83.3 & 86.7 & 86.0 & 84.8 & 83.8 & 85.3 \\
\hline 1980 & 83.3 & 83.3 & 82.7 & 80.8 & 78.1 & 76.7 & 75.9 & 77.0 & 77.9 & 78.6 & 79.7 & 79.7 & 83.1 & 78.5 & 76.9 & 79.3 & 79.5 \\
\hline 1981 & 79.0 & 79.2 & 79.3 & 79.3 & 79.6 & 79.3 & 79.6 & 78.8 & 78.0 & 77.0 & 75.6 & 74.2 & 79.2 & 79.4 & 78.8 & 75.6 & 78.3 \\
\hline 1982 & 72.6 & 74.6 & 73.9 & 73.1 & 72.7 & 72.6 & 71.8 & 71.4 & 70.9 & 69.9 & 69.6 & 69.0 & 73.7 & 72.8 & 71.4 & 69.5 & 71.8 \\
\hline 1983 & 70.6 & 70.8 & 71.8 & 72.5 & 73.4 & 73.9 & 74.8 & 75.6 & 77.2 & 77.6 & 77.7 & 77.5 & 71.1 & 73.2 & 75.9 & 77.6 & 74.4 \\
\hline 1984 & 79.3 & 79.5 & 79.8 & 80.0 & 80.1 & 80.3 & 80.4 & 80.2 & 79.8 & 79.6 & 79.5 & 79.0 & 79.5 & 80.1 & 80.1 & 79.4 & 79.8 \\
\hline 1985 & 78.9 & 79.1 & 79.3 & 79.2 & 79.4 & 78.9 & 78.3 & 78.8 & 78.8 & 77.9 & 78.5 & 78.2 & 79.1 & 79.2 & 78.6 & 78.2 & 78.8 \\
\hline 1986 & 79.1 & 78.6 & 77.8 & 78.7 & 78.5 & 78.1 & 78.2 & 78.6 & 78.4 & 78.9 & 79.1 & 79.9 & 78.5 & 78.5 & 78.4 & 79.3 & 78.7 \\
\hline 1987 & 79.1 & 80.2 & 80.3 & 80.6 & 80.7 & 81.4 & 81.8 & 81.5 & 81.5 & 82.5 & 82.8 & 83.1 & 79.9 & 80.9 & 81.6 & 82.8 & 81.3 \\
\hline 1988 & 82.9 & 83.1 & 82.9 & 83.7 & 83.5 & 83.4 & 83.8 & 84.0 & 84.0 & 84.1 & 84.8 & 85.1 & 83.0 & 83.5 & 83.9 & 84.7 & 83.8 \\
\hline 1989 & 85.7 & 84.5 & 85.0 & 85.0 & 84.2 & 84.1 & 83.0 & 83.1 & 82.7 & 82.1 & 82.2 & 82.1 & 85.1 & 84.4 & 82.9 & 82.1 & 83.6 \\
\hline 1990 & 81.8 & 82.5 & 82.6 & 81.8 & 82.0 & 81.8 & 81.6 & 81.7 & 81.5 & 80.9 & 79.7 & 79.0 & 82.3 & 81.9 & 81.6 & 79.9 & 81.4 \\
\hline 1991 & 78.2 & 77.5 & 76.6 & 76.8 & 77.1 & 78.1 & 78.2 & 78.2 & 79.0 & 78.9 & 78.6 & 78.1 & 77.5 & 77.3 & 78.5 & 78.5 & 77.9 \\
\hline 1992 & 78.0 & 78.4 & 79.0 & 79.4 & 79.5 & 79.4 & 80.0 & 79.6 & 79.7 & 79.9 & 80.2 & 80.0 & 78.5 & 79.4 & 79.8 & 80.0 & 79.4 \\
\hline 1993 & 80.4 & 80.4 & 80.4 & 80.6 & 80.2 & 80.0 & 80.1 & 79.7 & 80.4 & 80.5 & 80.7 & 81.2 & 80.4 & 80.3 & 80.0 & 80.8 & 80.4 \\
\hline 1994 & 81.1 & 81.1 & 81.8 & 82.2 & 82.5 & 82.5 & 82.6 & 82.8 & 82.7 & 83.1 & 83.4 & 84.0 & 81.3 & 82.4 & 82.7 & 83.5 & 82.5 \\
\hline 1995 & 84.1 & 83.7 & 83.5 & 82.9 & 82.6 & 82.6 & 81.7 & 82.3 & 82.5 & 82.1 & 81.8 & 81.5 & 83.8 & 82.7 & 82.1 & 81.8 & 82.6 \\
\hline 1996 & 80.9 & 81.4 & 80.8 & 81.3 & 81.5 & 81.8 & 81.9 & 82.0 & 82.1 & 81.7 & 82.1 & 82.2 & 81.0 & 81.6 & 82.0 & 82.0 & 81.6 \\
\hline 1997 & 82.1 & 82.7 & 82.5 & 82.5 & 82.4 & 82.5 & 82.4 & 83.0 & 83.0 & 83.0 & 83.0 & 82.7 & 82.5 & 82.5 & 82.8 & 82.9 & 82.7 \\
\hline 1998 & 83.0 & 82.4 & 82.1 & 82.2 & 81.8 & 80.8 & 80.1 & 81.5 & 80.9 & 81.2 & 80.6 & 80.4 & 82.5 & 81.6 & 80.9 & 80.7 & 81.4 \\
\hline 1999 & 80.5 & 80.6 & 80.4 & 80.3 & 80.5 & 80.3 & 80.3 & 80.7 & 80.5 & 80.8 & 81.0 & 81.1 & 80.5 & 80.4 & 80.5 & 81.0 & 80.6 \\
\hline 2000 & 81.0 & 81.1 & 81.5 & 81.4 & 81.6 & 81.7 & 81.0 & 80.7 & 80.5 & 79.8 & 79.2 & 78.4 & 81.2 & 81.6 & 80.7 & 79.1 & 80.7 \\
\hline 2001 & 77.6 & 77.2 & 76.7 & 76.0 & 75.8 & 75.0 & 75.1 & 74.6 & 73.7 & 73.1 & 72.9 & 72.8 & 77.2 & 75.6 & 74.5 & 72.9 & 75.0 \\
\hline
\end{tabular}

Note. See also general note to table A.1.

Annual averages of industrial production are calculated from indexes that are not seasonally adjusted. 
A.3. Revised data for industrial production, capacity, and utilization for total industry excluding selected high-technology industries

Seasonally adjusted data except as noted

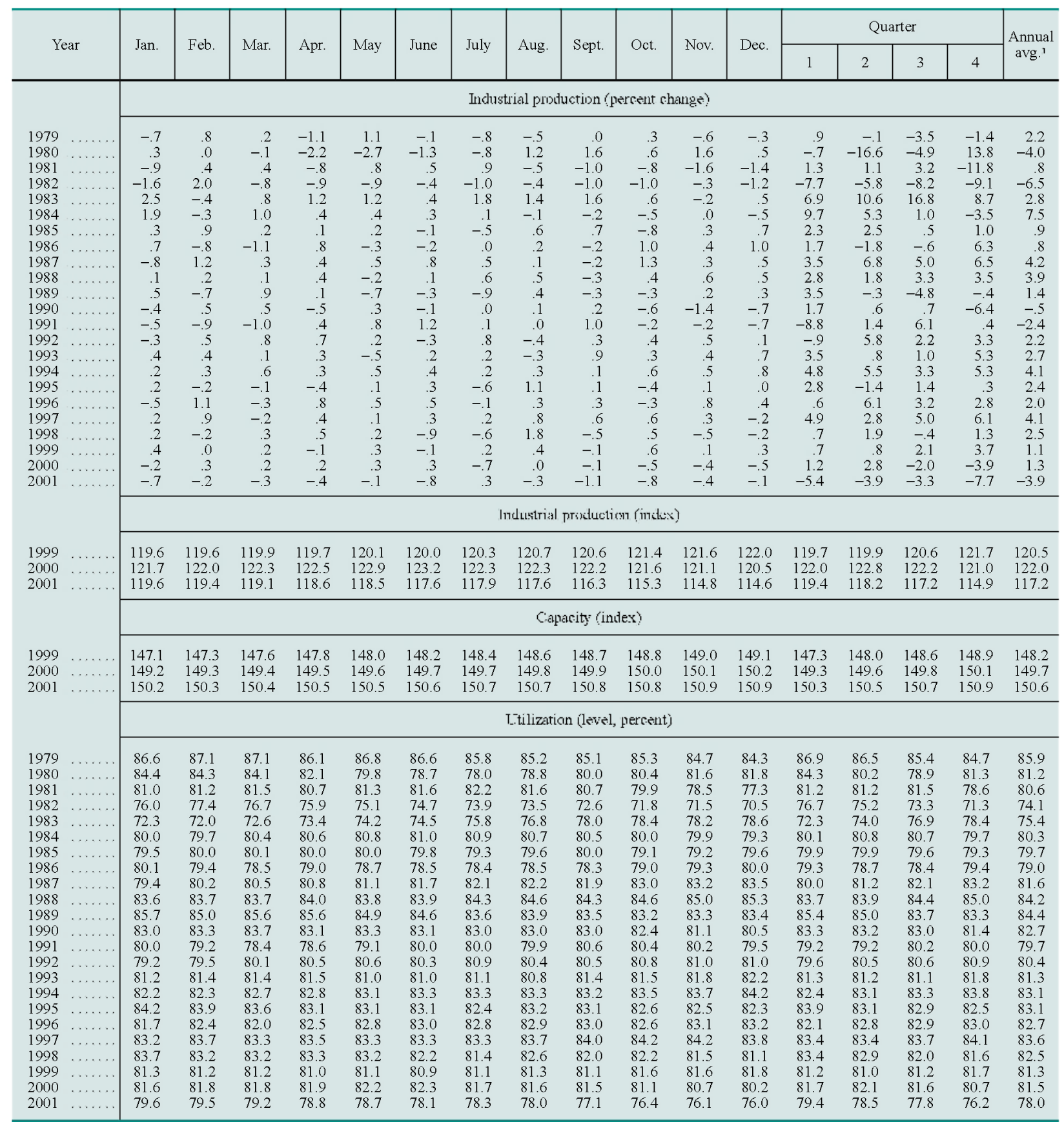

NotE. See also general note to table A.1.

Excludes computers, communications equipment, and semiconductors and related electronic components.
1. Annual averages of industrial production are calculated from indexes that are not seasonally adjusted. 
A.4. Revised data for industrial production, capacity, and utilization for manufacturing industries excluding selected high-technology industries

Seasonally adjusted data except as noted

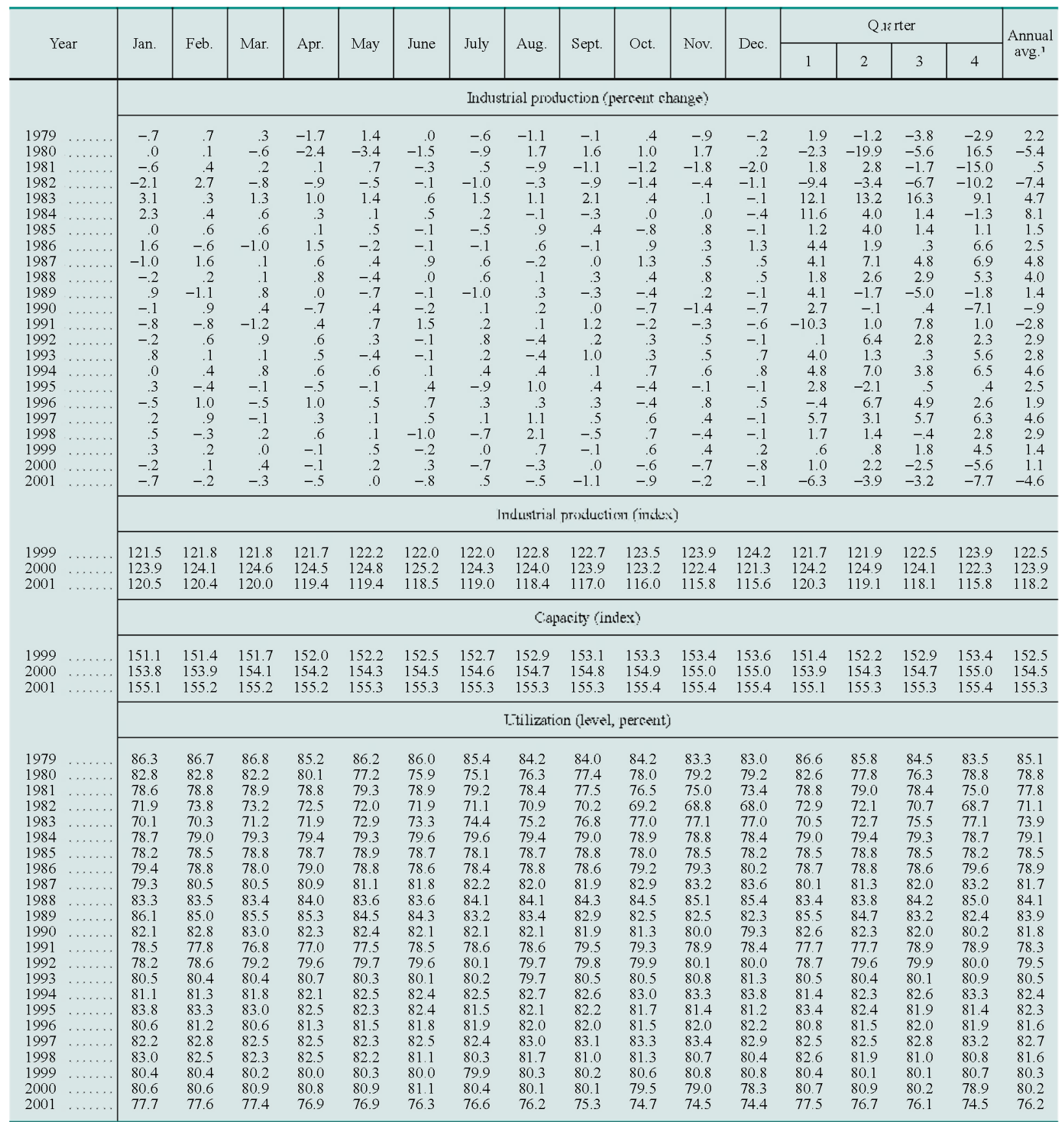

Note. See also general note to table A.1.

Excludes computers, communications equipment, and semiconductors and

1 Annual averages of industrial production are calculated from indexes that related electronic components. 
A.5. Rates of change in industrial production, by market and industry group, 1997-2001

\begin{tabular}{|c|c|c|c|c|c|c|c|c|c|c|c|}
\hline \multirow[t]{2}{*}{ Item } & \multirow{2}{*}{$\begin{array}{l}\text { SIC } \\
\operatorname{code}^{1}\end{array}$} & \multicolumn{5}{|c|}{$\begin{array}{l}\text { Revis ed rate of change } \\
\text { (percent) }\end{array}$} & \multicolumn{5}{|c|}{ 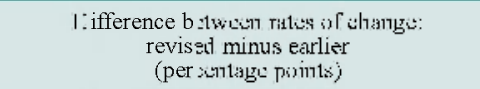 } \\
\hline & & 1997 & 1998 & 1999 & 2000 & 2001 & 1997 & 1998 & 1999 & 2000 & 2001 \\
\hline Total index & $\cdots$ & 7.4 & 3.5 & 4.3 & 2.6 & -6.0 & .2 & .3 & -.7 & -1.6 & -.1 \\
\hline \multicolumn{12}{|l|}{ MLAkKLLT Cinoly } \\
\hline Products $\ldots . . . .$. & . . & 6.0 & 2.9 & 2.6 & 1.8 & -5.3 & .0 & -.3 & -8 & -1.2 & .3 \\
\hline Consumer goods & $\ldots$ & 3.7 & .2 & 2.5 & .7 & -2.0 & -3 & .0 & -6 & 1 & 6 \\
\hline Durable .... & $\ldots$ & 7.6 & 5.6 & 6.7 & -4.2 & -2.7 & -8 & 1.3 & -1.5 & 2 & -.1 \\
\hline Automotive products & $\ldots$ & 8.8 & 7.4 & 5.8 & -7.3 & 3.7 & -1.8 & 2.1 & 2.5 & -4 & 4 \\
\hline Home electronics ... & $\cdots$ & $\begin{array}{r}0.0 \\
19.5\end{array}$ & 12.4 & 30.8 & 7.4 & -24.3 & -.3 & .7 & -22.6 & 4.5 & -3.5 \\
\hline Appliances, furniture & & & & & & & & & & & \\
\hline and carpeting & $\ldots$ & 4.4 & 6.0 & 2.6 & -2.0 & -1.9 & .2 & -.9 & -3.4 & -.7 & -.5 \\
\hline Miscellaneous ... & $\ldots$ & 4.4 & -.4 & 3.8 & -2.0 & -11.8 & -.1 & 2.1 & -8 & 2.2 & -2.8 \\
\hline Nondurable ...... & $\ldots$ & 2.6 & -1.3 & 1.3 & 2.2 & -1.8 & -1 & -.4 & -4 & 2 & .8 \\
\hline Non-energy & $\ldots$ & 2.8 & -1.0 & 1.2 & 1.1 & -8 & -.1 & -.5 & -4 & -1 & 1.1 \\
\hline Foods and tobacco & $\ldots$ & 1.9 & -.1 & .7 & .4 & -1.4 & -.3 & -.7 & 4 & -.5 & .5 \\
\hline 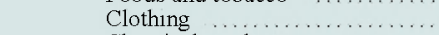 & $\ldots$ & -3.3 & -6.4 & -2.8 & -8.5 & -11.3 & -.2 & 1.8 & 2.1 & -4.1 & 2.0 \\
\hline Chemical products...... & $\ldots$ & 4.9 & 2.5 & 4.4 & 5.4 & 6.3 & -.5 & -8 & -1.4 & 2.9 & 2.8 \\
\hline Paper products ... & $\ldots$ & 6.5 & -6.1 & 1 & 2.4 & -5.1 & 1.3 & -8 & -2.5 & -8 & .9 \\
\hline Energy ........... & $\ldots$ & 1.6 & -3.4 & 2.3 & 8.6 & -7.0 & -.2 & .6 & -3 & 1.9 & -1.0 \\
\hline Business equipment & $\ldots$ & 14.0 & 8.4 & 4.4 & 5.8 & -12.9 & .8 & -.6 & -1.2 & -5.2 & -1.2 \\
\hline Transit & $\ldots$ & 25.5 & 15.4 & -3.9 & -7.5 & -13.1 & 2.1 & 2.5 & 5.0 & 1.3 & -.2 \\
\hline Information processing $\ldots \ldots \ldots$ & $\ldots$ & 17.9 & 14.4 & 15.6 & 16.4 & -12.4 & 1.4 & -2.4 & -5.4 & -6.7 & -3.3 \\
\hline Industrial and other .. & $\ldots$ & 5.8 & -.5 & -1.8 & 3.0 & -13.4 & -.3 & -.4 & -2 & -5.6 & -.1 \\
\hline Defense and space equipment & $\ldots$ & -2.5 & 5.5 & -7.6 & -2.2 & -.4 & 2.5 & -2.7 & -4.6 & 1.1 & -1.3 \\
\hline Construction supplies ........ & $\ldots$ & 4.0 & 6.6 & 3.9 & .5 & -4.6 & 1 & -9 & -6 & 2 & 9 \\
\hline Business supplies ............ & $\cdots$ & 4.2 & 1.3 & 1.4 & .9 & -6.3 & -.6 & -.5 & -8 & -3 & 9 \\
\hline Materials . & $\ldots$ & 9.5 & 4.5 & 7.2 & 3.9 & -6.9 & .1 & .8 & -8 & -2.4 & -.5 \\
\hline Durable & $\cdots$ & 14.3 & 8.8 & 10.4 & 7.5 & -8.6 & .2 & 1.6 & -.5 & -4.6 & -.7 \\
\hline Consumer parts & $\ldots$ & 8.5 & 3.6 & 5.9 & -2.1 & -4.8 & -1.8 & 3.5 & -1.2 & -2.3 & 2.9 \\
\hline Equipment parts $\ldots \ldots \ldots \ldots \ldots$ & $\ldots$ & 28.6 & 22.0 & 19.7 & 25.1 & -11.0 & 2.5 & 1.4 & -2.3 & -11.0 & -3.7 \\
\hline Other ............. & $\ldots$ & 4.7 & .2 & 4.4 & -3.1 & -8.1 & -.7 & .7 & 9 & -1.3 & 8 \\
\hline Nondurable & $\ldots$ & 5.7 & -3.3 & 3.9 & -4.7 & -5.9 & .5 & -.5 & -1.7 & .5 & 1.3 \\
\hline Textile ............... & $\ldots$ & 4.9 & -6.2 & 4.6 & -12.8 & -12.0 & 1.5 & 2.2 & 5.9 & -3.2 & 3.3 \\
\hline Paper ........... & $\ldots$ & 4.3 & -2.7 & 4.5 & -4.5 & -1.9 & -.3 & .2 & 3 & .0 & .9 \\
\hline Chemical. & $\ldots$ & 6.5 & -5.6 & 5.3 & -4.2 & -7.8 & .2 & -1.6 & -4.2 & 2.0 & 1.0 \\
\hline Energy $\quad \ldots \ldots \ldots \ldots \ldots \ldots \ldots \ldots$ & $\ldots$ & .1 & -4 & 6 & 1.6 & -3.4 & 0 & 3 & 1 & 2 & -2.4 \\
\hline \multicolumn{12}{|l|}{ INDUSIRY CiROLY } \\
\hline Manufacturing & $\ldots$ & 8.3 & 4.3 & 4.8 & 2.3 & -6.3 & .3 & .3 & -8 & -1.9 & .1 \\
\hline Durable.... & & 11.9 & 8.4 & 6.9 & 4.8 & -8.5 & 4 & .4 & -1.3 & -3.6 & -.5 \\
\hline Lumber and products . & 24 & 2.8 & 5.6 & 1.8 & -6.8 & -.3 & -9 & .1 & 1.3 & .6 & -.3 \\
\hline Furniture and fixtures .. & 25 & 8.1 & 6.1 & 5.0 & .8 & -7.4 & .2 & -.2 & 1.9 & -4.8 & .0 \\
\hline Stone, clay, and glass products ... & 32 & 2.5 & 5.8 & 3.2 & -9 & -3.7 & -9 & .2 & 1.0 & -1.8 & 5 \\
\hline Primary metals ................. & 33 & 5.8 & -3.5 & 6.7 & -5.2 & -13.2 & -.2 & .0 & -1.3 & .5 & -2.1 \\
\hline 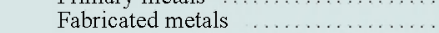 & 34 & 6.5 & 1.7 & 1.2 & 2.2 & -7.3 & .3 & 2 & -.5 & 1.3 & 1.5 \\
\hline Industrial machinery and equipment & 35 & 7.8 & 9.1 & 7.1 & 7.5 & -12.0 & .5 & -2.5 & -6.5 & -6.9 & 1.4 \\
\hline Electrical machinery .............. & 36 & 31.3 & 22.2 & 23.7 & 27.3 & -14.7 & 2.9 & 1.8 & -1.5 & -11.7 & -4.6 \\
\hline Motor vehicles and parts ......... & 371 & 14.3 & 6.7 & 7.5 & -8.0 & -.3 & -1.7 & 3.5 & 1.6 & -1.6 & .8 \\
\hline Aerospace and miscellaneous & & & & & & & & & & & \\
\hline transportion equipment & $372-6,9$ & 13.7 & 11.3 & -8.9 & .2 & -9.3 & .8 & 9 & 2.7 & .5 & .0 \\
\hline Instruments ................. & & 2.9 & 4.2 & .6 & 1.3 & -5.0 & .0 & 3 & -3.9 & -.6 & -2.1 \\
\hline 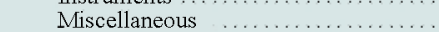 & 39 & 2.0 & -.5 & 4.8 & -1.0 & -9.1 & -1.1 & -1.2 & -1.9 & -1.0 & -1.8 \\
\hline Nondurable ..... & & 3.9 & -.7 & 2.1 & -.7 & -3.6 & -.3 & -3 & -5 & .0 & 1.0 \\
\hline Food and tobacco products & 20,21 & 2.6 & .1 & .7 & 4 & $=1.5$ & -.1 & -.7 & 4 & -4 & .5 \\
\hline Textile mill products ................ & 22 & .7 & -6.1 & 4 & -10.6 & -10.6 & -.8 & 4 & .6 & -2.7 & 3.3 \\
\hline Apparel products .................. & 23 & 1.8 & -3.1 & 3 & -6.7 & -11.1 & 2.0 & 3.3 & 4.3 & -1.4 & -4 \\
\hline Paper and products $\ldots \ldots \ldots \ldots \ldots \ldots$ & 26 & 4.5 & -.5 & 2.3 & -3.0 & -4.3 & -4 & -4 & -6 & .1 & 1.2 \\
\hline Printing and publishing. & 27 & 5.1 & -2.4 & .7 & .5 & -7.7 & .0 & -.6 & -1.1 & -1.0 & 1.3 \\
\hline Chemicals and products & 28 & 4.8 & -.6 & 4.1 & .8 & -.6 & -.5 & -.7 & -2.6 & 2.2 & 1.9 \\
\hline Petroleum products...$\ldots \ldots \ldots \ldots$ & 29 & 3.0 & 1.3 & -.6 & 2.0 & -1.9 & -.1 & -.8 & -7 & .8 & -.4 \\
\hline Rubber and plastics products .. & 30 & 6.1 & 3.0 & 5.9 & -2.8 & -4.9 & -.9 & 1.4 & 2.3 & -.9 & .1 \\
\hline Mining . & $10-14$ & 1.4 & -5.3 & -.2 & 1.7 & -1.7 & -.1 & .1 & 3 & .3 & -2.2 \\
\hline Utilities & $491,2,3 \mathrm{pt}$ & 2.0 & -.6 & 2.2 & 6.8 & -5.9 & -.3 & .7 & -1 & .2 & -.7 \\
\hline Electric & . . & 2.8 & 1.8 & 1.8 & 5.2 & -3.9 & -4 & .3 & .1 & -1.1 & -1 \\
\hline 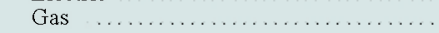 & $\ldots$ & -1.4 & -11.5 & 4.7 & 12.9 & -12.5 & .1 & .4 & 1 & 5.4 & -3.1 \\
\hline
\end{tabular}

NoTE. Rates of change are calculated as the percent change in the seasonally adjusted index from the fourth quarter of the previous year to the fourth quarter of the year specified. For 2001, the differences between rates of change are calculated from annualized rates between the fourth quarter of 2000 and the 1 Standard Industrial Classification; see Executive Office of the President Office of Management and Budget, Standard Industrial Classification Manual, 1987 (U.S. Government Printing Office, 1987).

pt. Part of classification. 
A.6. Rates of change in industrial production, special aggregates and selected detail, 1997-2001

\begin{tabular}{|c|c|c|c|c|c|c|c|c|c|c|c|}
\hline \multirow[t]{2}{*}{ Market group } & \multirow{2}{*}{$\begin{array}{l}\text { SIC } \\
\text { code }^{1}\end{array}$} & \multicolumn{5}{|c|}{$\begin{array}{l}\text { Revisi } d \text { rate of clange } \\
\text { (percent) }\end{array}$} & \multicolumn{5}{|c|}{ 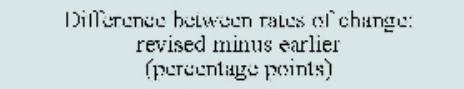 } \\
\hline & & 1997 & 1998 & 1999 & 2000 & 2001 & 1997 & 1998 & 1999 & 2000 & 2001 \\
\hline Total index & $\cdots$ & 7.4 & 3.5 & 4.3 & 2.6 & -6.0 & .2 & .3 & -.7 & -1.6 & -.1 \\
\hline Energy & $\therefore$. & 1.4 & -2.5 & 1.2 & 4.5 & -4.0 & -.2 & .6 & .1 & .4 & -1.5 \\
\hline Consumer products & $\therefore$ & 1.6 & -3.4 & 2.3 & 8.6 & -7.0 & -.2 & .6 & -3 & 1.9 & -1.0 \\
\hline Commercial products & $\ldots$ & 5.0 & -1 & .7 & 7.3 & 9 & .1 & 4 & -3 & 1 & 9 \\
\hline Oil and gas drilling & $=\therefore$ & 8.7 & -26.3 & 5.7 & 19.1 & -6.8 & .0 & .1 & .1 & .2 & -2 \\
\hline Converted fuel & & 1.2 & -.2 & 2.7 & 5.6 & -8.0 & .8 & .0 & -1 & .4 & .3 \\
\hline Primary materials & & -.5 & -.5 & -.6 & -.2 & -1.4 & -.4 & .5 & 1 & .0 & -3.0 \\
\hline Non-energy & & 8.4 & 4.3 & 4.8 & 2.3 & -6.3 & .3 & .3 & -8 & -1.9 & .2 \\
\hline Selected high-technology industries & & 40.2 & 35.8 & 34.0 & 39.5 & -15.9 & 4.5 & -1.4 & -6.6 & -15.8 & -5.1 \\
\hline Computers and office equipment & 357 & 24.5 & 40.5 & 33.0 & 33.4 & -10.4 & 3.0 & -13.5 & -21.3 & -8.7 & -1.5 \\
\hline Communications equipment & 366 & 27.6 & 6.5 & 21.1 & 25.4 & -24.3 & 3.0 & -2.5 & 7.7 & -10.2 & -9.0 \\
\hline & & & & & & & & & & & \\
\hline $\begin{array}{l}\text { electronic components } \\
\text { Excluding selected high- }\end{array}$ & $3672-9$ & 55.0 & 50.5 & 41.1 & 48.6 & -14.4 & 6.1 & 4.9 & -6.7 & -24.8 & -4.3 \\
\hline technology industries & & 5.3 & 1.4 & 2.0 & -1.4 & -5.3 & -.3 & .1 & -.3 & -.7 & .8 \\
\hline Motor vehicles and parts & 371 & 14.3 & 6.7 & 7.5 & -8.0 & -3 & -1.7 & 3.5 & 1.6 & -1.6 & 8 \\
\hline Motor vehicles & 3711,3 & 14.2 & 9.0 & 6.3 & -11.4 & 2.1 & .0 & 2.1 & 4.2 & 9 & -1.0 \\
\hline Motor vehicle parts & 3714 & 14.1 & 3.7 & 9.2 & -1.2 & -2.1 & -4.0 & 5.4 & -1.6 & -4.5 & 2.1 \\
\hline Excluding motor vehicles and parts & & 4.6 & 1.0 & 1.5 & -8 & -5.7 & -.2 & -.1 & -.5 & -.6 & .7 \\
\hline Consumer goods $\ldots \ldots \ldots$ & & 3.2 & -.5 & 1.9 & .5 & -2.0 & -.1 & -.2 & -.6 & .1 & 6 \\
\hline Business equipment. & $\ldots$ & 9.0 & 4.1 & -3.1 & 1.9 & -11.9 & -.3 & .9 & -8 & -3.4 & 4 \\
\hline Business supplies ... & $\ldots$ & 4.0 & 1.7 & 1.6 & -.5 & -8.1 & -.8 & -.7 & -1.0 & -.4 & 1.1 \\
\hline Materials .......... & $=\ldots$ & 5.2 & -8 & 3.3 & -2.7 & -6.9 & -2 & 2 & 0 & -.4 & .7 \\
\hline \multicolumn{12}{|l|}{$\begin{array}{l}\text { Special aggregates } \\
\text { Measures excluding selected high- } \\
\text { technology industries }\end{array}$} \\
\hline Total industry. .. & . & 4.7 & .9 & 1.8 & -.5 & -5.1 & -.3 & .2 & -3 & -.5 & 4 \\
\hline Manufacturing & $\ldots$ & 5.2 & 1.4 & 1.9 & -1.3 & -5.3 & -2 & .2 & -4 & -.7 & .7 \\
\hline Durable & & 6.5 & 3.3 & 1.8 & -1.8 & -7.0 & -3 & .7 & -4 & -1.4 & .5 \\
\hline Industrial machiner: & $351-6,8,9$ & 3.4 & .5 & -.4 & 1 & -12.5 & -.2 & -.1 & -1.6 & -4.8 & 2.5 \\
\hline Electrical machinery & $361-5,9,71$ & 5.2 & .9 & 3.9 & -1.2 & -8.4 & -.2 & 1.2 & -2.6 & -1.2 & -1.2 \\
\hline \multicolumn{12}{|l|}{$\begin{array}{l}\text { Measures excluding motor } \\
\text { vehicles and parts }\end{array}$} \\
\hline Total industry & $\ldots$ & 7.0 & 3.3 & 4.1 & 3.4 & -6.3 & .2 & .1 & -9 & -1.5 & -.2 \\
\hline Manufacturing & $\ldots$ & 7.9 & 4.2 & 4.5 & 3.2 & -6.8 & 4 & .1 & -1.0 & -1.8 & .0 \\
\hline Durable .... & $\ldots$ & 11.6 & 8.6 & 6.8 & 6.8 & -9.7 & .7 & .0 & -1.8 & -3.7 & -.8 \\
\hline Primary processing : & $\ldots$ & 11.0 & 5.7 & 8.0 & 3.7 & -7.1 & .5 & 1.3 & -9 & -1.9 & .0 \\
\hline Advanced processing & $\ldots$ & 6.6 & 3.5 & 2.8 & 1.4 & -5.8 & 2 & -4 & -9 & -1.9 & 3 \\
\hline
\end{tabular}

NoTE. See also general note to table A.5.

3 Advanced-processing manufacturing includes foods, tobacco products,

Standard Industrial Classification; see table A 5, note 1

2. Primary-processing manufacturing includes textile mill products; paper and products; industrial chemicals, synthetic materials, and fertilizers; petroleum products; rubber and plastics products; lumber and products; primary metals; fabricated metals; stone, clay, and glass products; semiconductors and apparel products, printing and publishing, chemical products and other agricultural chemicals, leather and products, furniture and fixtures, industrial and commercial machinery and computer equipment, electrical machinery except semiconductors and related electronic components, transportation equipment related electronic components; and motor vehicle parts.

except motor vehicle parts, instruments, and miscellaneous manufactures. 
A.7. Capacity utilization rates, by industry group, 1967-2001

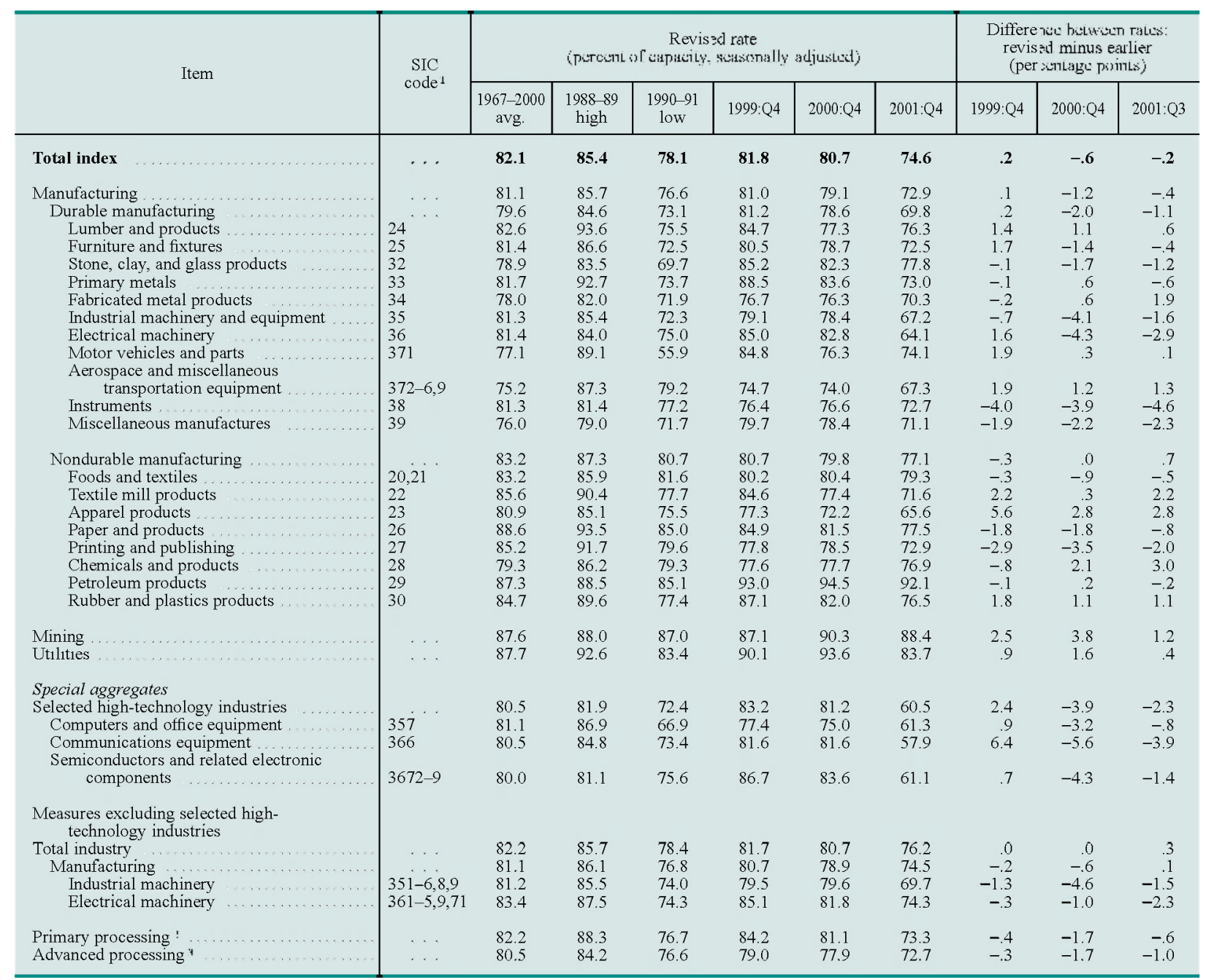

Note. The "high" column refers to periods in which utilization generally peaked; the "low" column refers to recession years in which utilization generally bottomed out. The monthly highs and lows are specific to each series, and all did not occur in the same month.

1 Standard Industrial Classification; see table A.5, note 1.

2 Primary-processing manufacturing includes textile mill products; paper and products; industrial chemicals, synthetic materials, and fertilizers; petroleum products; rubber and plastics products; lumber and products; primary metals;

fabricated metals; stone, clay, and glass products; semiconductors and related electronic components; and motor vehicle parts.

3 Advanced-processing manufacturing includes foods, tobacco products, apparel products, printing and publishing, chemical products and other agricultural chemicals, leather and products, furniture and fixtures, industrial and commercial machinery and computer equipment, electrical machinery except semiconductors and related electronic components, transportation equipment except motor vehicle parts, instruments, and miscellaneous manufactures. 
A.8. Rates of change in capacity, by industry group, 1997-2001

\begin{tabular}{|c|c|c|c|c|c|c|c|c|c|c|}
\hline \multirow[t]{2}{*}{ Industry group } & \multicolumn{5}{|c|}{$\begin{array}{l}\text { Revi: ed rate of c camesci } \\
\text { (percent) }\end{array}$} & \multicolumn{5}{|c|}{ 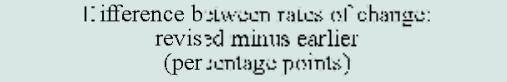 } \\
\hline & 1997 & 1998 & 1999 & 2000 & 2001 & 1997 & 1998 & 1999 & 2000 & 2001 \\
\hline Total index & 6.4 & 6.4 & 3.9 & 4.0 & 1.7 & .4 & -.1 & -.7 & -.5 & -.7 \\
\hline Manufacturing & 7.1 & 7.2 & 4.5 & 4.7 & 1.6 & 5 & -.1 & -6 & -3 & -1.0 \\
\hline Durable manufacturing & 10.2 & 10.4 & 6.6 & 8.1 & 3.0 & 9 & 2 & -1.7 & -.7 & -1.9 \\
\hline Nondurable manufacturing & 3.3 & 3.2 & 1.7 & .4 & -.2 & -1 & -9 & 4 & -.5 & -.1 \\
\hline Mining $\ldots$ & 1.3 & -.6 & -2.4 & -1.9 & .4 & -6 & -.5 & -.9 & -1.1 & 1.8 \\
\hline Ut1lities & .6 & .1 & 2.4 & 2.9 & 5.2 & -4 & -1.0 & .1 & -.5 & 1.1 \\
\hline Special aggregates & & & & & & & & & & \\
\hline Selected high-technology industries & 44.4 & 36.6 & 28.6 & 42.9 & 12.9 & 4.1 & -2.8 & -9.2 & -4.7 & -8.6 \\
\hline high-technology industries & 3.6 & 4.4 & 2.0 & 1.0 & .3 & .0 & -.1 & .0 & -.3 & -.3 \\
\hline Primary processing ${ }^{\prime}$ & 9.4 & 9.8 & 5.0 & 7.8 & 2.7 & 1.0 & 4 & .1 & -.3 & -1.4 \\
\hline Advanced processing ! & 5.6 & 5.5 & 4.2 & 2.9 & 9 & .7 & -2 & -1.0 & -.1 & -9 \\
\hline
\end{tabular}

Note. See also general note to table A.5.

1 Primary-processing manufacturing includes textile mill products; paper and products; industrial chemicals, synthetic materials, and fertilizers; petroleum products; rubber and plastics products; lumber and products; primary metals; fabricated metals; stone, clay, and glass products; semiconductors and related electronic components; and motor vehicle parts.

2 Advanced-processing manufacturing includes foods, tobacco products, apparel products, printing and publishing, chemical products and other agricultural chemicals, leather and products, furniture and fixtures, industrial and commercial machinery and computer equipment, electrical machinery except semiconductors and related electronic components, transportation equipment except motor vehicle parts, instruments, and miscellaneous manufactures. 
A.9. Annual proportions in industrial production, by market and industry group, 1994-01

\begin{tabular}{|c|c|c|c|c|c|c|c|c|c|}
\hline Item & $\begin{array}{l}\text { SIC } \\
\text { code }^{1}\end{array}$ & 1994 & 1995 & 1996 & 1997 & 1998 & 1999 & 2000 & 2001 \\
\hline Total index & $\cdots$ & 100.0 & 100.0 & 100.0 & 100.0 & 100.0 & 100.0 & 100.0 & 100.0 \\
\hline \multicolumn{10}{|l|}{ MARKFT CiROIT } \\
\hline Products & $\ldots$ & 60.2 & 59.5 & 59.9 & 60.6 & 61.5 & 60.8 & 59.9 & 61.9 \\
\hline Consumer goods & $\ldots$ & 28.6 & 28.3 & 28.4 & 28.3 & 28.7 & 28.6 & 28.4 & 30.4 \\
\hline Durable $\ldots .$. & $\ldots$ & 6.2 & 6.1 & 6.3 & 6.3 & 6.3 & 6.7 & 6.5 & 6.5 \\
\hline Automotive products ................. & $\ldots$ & 2.7 & 2.7 & 2.8 & 2.9 & 2.9 & 3.3 & 3.4 & 3.5 \\
\hline Home electronics $\ldots \ldots \ldots \ldots \ldots \ldots \ldots$ & $\cdots$ & .5 & .5 & .5 & .5 & .5 & .5 & .4 & .3 \\
\hline $\begin{array}{c}\text { Appliances, furniture, } \\
\text { and carpeting }\end{array}$ & $\ldots$ & 1.4 & 1.3 & 1.3 & 1.3 & 1.4 & 1.3 & 1.3 & 1.3 \\
\hline Miscellaneous ...... & $\ldots$ & 1.6 & 1.6 & 1.6 & 1.6 & 1.6 & 1.5 & 1.5 & 1.4 \\
\hline Nondurable $\ldots \ldots \ldots \ldots \ldots \ldots \ldots \ldots \ldots$ & $\ldots$ & 22.4 & 22.2 & 22.1 & 22.0 & 22.3 & 21.9 & 21.8 & 23.9 \\
\hline 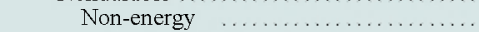 & $\ldots$ & 19.3 & 19.1 & 19.0 & 19.2 & 19.5 & 18.8 & 18.6 & 20.6 \\
\hline Foods and tobacco $\ldots \ldots \ldots \ldots$ & $\ldots$ & 9.7 & 9.7 & 9.6 & 9.7 & 10.1 & 10.0 & 10.1 & 11.2 \\
\hline Clothing ............ & $\ldots$ & 2.3 & 2.1 & 2.0 & 1.9 & 1.7 & 1.5 & 1.4 & 1.3 \\
\hline Chemical products & $\ldots$ & 4.5 & 4.5 & 4.5 & 4.6 & 4.7 & 4.5 & 4.3 & 5.1 \\
\hline Paper products $\quad \ldots \ldots \ldots \ldots \ldots \ldots$ & $\ldots$ & 2.8 & 2.8 & 2.8 & 3.0 & 3.0 & 2.8 & 2.8 & 3.0 \\
\hline Energy $\ldots \ldots \ldots \ldots \ldots$ & $\ldots$ & 3.1 & 3.1 & 3.1 & 2.9 & 2.8 & 3.1 & 3.2 & 3.4 \\
\hline Business equipment $\quad \ldots \ldots \ldots \ldots \ldots \ldots \ldots \ldots \ldots \ldots \ldots \ldots$ & $\cdots$ & 13.3 & 13.4 & 13.7 & 14.3 & 14.7 & 14.2 & 13.7 & 13.1 \\
\hline Transit $\ldots \ldots \ldots \ldots \ldots \ldots \ldots \ldots \ldots \ldots \ldots$ & $\ldots$ & 2.4 & 2.3 & 2.3 & 2.6 & 3.1 & 3.2 & 3.1 & 2.9 \\
\hline Information processing & $\ldots$ & 5.2 & 5.2 & 5.4 & 5.6 & 5.6 & 5.5 & 5.5 & 5.0 \\
\hline Industrial and other .. & $\ldots$ & 5.6 & 5.9 & 6.0 & 6.0 & 6.0 & 5.4 & 5.2 & 5.1 \\
\hline Defense and space equipment $\ldots \ldots \ldots \ldots \ldots$ & $\ldots$ & 2.7 & 2.5 & 2.3 & 2.1 & 2.2 & 2.1 & 1.9 & 2.0 \\
\hline 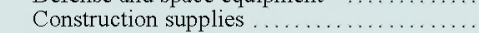 & $\ldots$ & 5.7 & 5.6 & 5.7 & 5.9 & 6.2 & 6.3 & 6.4 & 6.6 \\
\hline Business supplies $\quad \ldots \ldots \ldots \ldots \ldots \ldots \ldots$ & $\cdots$ & 9.0 & 8.9 & 8.9 & 8.9 & 8.9 & 8.8 & 8.7 & 8.9 \\
\hline Materials . & $\ldots$ & 39.8 & 40.5 & 40.1 & 39.4 & 38.5 & 39.2 & 40.1 & 38.1 \\
\hline Durable. & $\ldots$ & 22.2 & 22.8 & 23.0 & 23.2 & 23.1 & 23.2 & 23.5 & 22.4 \\
\hline Consumer parts & $\ldots$ & 4.6 & 4.5 & 4.5 & 4.5 & 4.6 & 4.8 & 4. 7 & 4.6 \\
\hline Equipment parts ... & $\ldots$ & 7.6 & 8.2 & 8.4 & 8.4 & 8.5 & 8.5 & 9.0 & 8.1 \\
\hline Other $\ldots \ldots \ldots$ & $\ldots$ & 9.9 & 10.1 & 10.2 & 10.2 & 10.1 & 9.9 & 9.7 & 9.6 \\
\hline Nondurable & $\cdots$ & 9.4 & 9.3 & 8.5 & 8.6 & 8.3 & 8.0 & 7.9 & 7.6 \\
\hline Textile & $\ldots$ & 1.1 & 1.0 & 1.0 & 1.0 & .9 & 9 & .8 & 8 \\
\hline Paper. & $\ldots$ & 2.0 & 2.1 & 1.7 & 1.7 & 1.7 & 1.7 & 1.6 & 1.6 \\
\hline Chemical & $\ldots$ & 4.2 & 4.1 & 3.9 & 4.0 & 3.8 & 3.6 & 3.7 & 3.5 \\
\hline Energy $\ldots$ & $\ldots$ & 8.3 & 8.4 & 8.6 & 7.7 & 7.1 & 8.0 & 8.8 & 8.1 \\
\hline \multicolumn{10}{|l|}{ TVDUSTRY CiRotT } \\
\hline Manufecturing & $\ldots$ & 86.5 & 86.6 & 86.5 & 87.6 & 88.5 & 87.7 & 86.5 & 86.7 \\
\hline Durable.... & $\ldots$ & 46.2 & 46.6 & 47.3 & 48.1 & 48.9 & 48.8 & 48.3 & 46.8 \\
\hline Lumber and products ................. & 24 & 2.2 & 2.1 & 2.1 & 2.1 & 2.1 & 2.3 & 2.2 & 2.2 \\
\hline Furniture and fixtures & 25 & 1.3 & 1.4 & 1.4 & 1.5 & 1.6 & 1.6 & 1.5 & 1.6 \\
\hline Stone, clay, and glass products ...... & 32 & 2.2 & 2.2 & 2.3 & 2.3 & 2.4 & 2.5 & 2.5 & 2.7 \\
\hline Primary metals $\quad \ldots \ldots \ldots \ldots \ldots \ldots \ldots$ & 33 & 3.5 & 3.5 & 3.5 & 3.6 & 3.4 & 3.3 & 3.2 & 29 \\
\hline Fabricated metals & 34 & 5.2 & 5.3 & 5.4 & 5.6 & 5.8 & 5.7 & 5.8 & 5.8 \\
\hline Industrial machinery and equipment ...... & 35 & 8.4 & 8.8 & 9.0 & 9.1 & 9.0 & 8.4 & 8.2 & 7.7 \\
\hline Electrical machinery .................... & 36 & 7.8 & 8.3 & 8.5 & 8.7 & 8.7 & 8.7 & 9.1 & 7.8 \\
\hline Motor vehicles and parts $\ldots$ & 371 & 5.5 & 5.4 & 5.4 & 5.6 & 5.6 & 6.4 & 6.5 & 6.4 \\
\hline Aerospace and miscellaneous & & & & & & & & & \\
\hline transportion equipment & $372-6,9$ & 3.8 & 3.5 & 3.4 & 3.6 & 4.3 & 4.1 & 3.9 & 4.1 \\
\hline Instruments $\ldots \ldots \ldots \ldots \ldots \ldots \ldots \ldots \ldots$ & 38 & 4.9 & 4.8 & 4.8 & 4.7 & 4.7 & 4.6 & 4.4 & 4.5 \\
\hline Miscellaneous $\quad . \ldots \ldots \ldots \ldots \ldots \ldots \ldots$ & 39 & 1.3 & 1.3 & 1.3 & 1.3 & 1.3 & 1.2 & 1.2 & 1.2 \\
\hline Nondurable .......... & & 40.3 & 40.0 & 39.2 & 39.6 & 39.6 & 38.9 & 38.2 & 39.9 \\
\hline Food and tobacco products $\ldots \ldots \ldots \ldots$ & 20,21 & 10.5 & 10.5 & 10.3 & 10.3 & 10.8 & 10.6 & 10.7 & 11.8 \\
\hline Textile mill products $\ldots \ldots \ldots \ldots \ldots \ldots$ & 22 & 1.8 & 1.7 & 1.6 & 1.5 & 1.5 & 1.4 & 1.3 & 1.2 \\
\hline Apparel products .......................... & 23 & 2.1 & 2.0 & 1.9 & 1.9 & 1.7 & 1.7 & 1.5 & 1.5 \\
\hline Paper and products .................... & 26 & 3.8 & 3.9 & 3.5 & 3.5 & 3.5 & 3.4 & 3.3 & 3.3 \\
\hline Printing and publishing & 27 & 6.6 & 6.6 & 6.6 & 6.9 & 6.8 & 6.5 & 6.4 & 6.6 \\
\hline Chemicals and products $\ldots \ldots \ldots \ldots$ & 28 & 10.0 & 9.9 & 9.7 & 9.9 & 9.7 & 9.3 & 9.2 & 9.7 \\
\hline Petroleum products & 29 & 1.5 & 1.5 & 1.7 & 1.6 & 1.6 & 1.9 & 1.9 & 1.9 \\
\hline Rubber and plastics products ............ & 30 & 3.8 & 3.7 & 3.7 & 3.8 & 3.9 & 3.9 & 3.8 & 3.8 \\
\hline Mining . & 10,14 & 5.9 & 5.9 & 6.2 & 5.6 & 5.0 & 5.8 & 6.8 & 6.2 \\
\hline Utılities & $491,2,3, \mathrm{pt}$ & 7.6 & 7.5 & 7.3 & 6.8 & 6.5 & 6.4 & 6.7 & 7.1 \\
\hline Electric .... & $\ldots$ & 6.0 & 5.9 & 5.8 & 5.5 & 5.3 & 5.2 & 5.2 & 5.6 \\
\hline 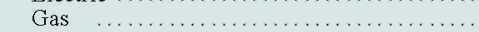 & $\ldots$ & 1.6 & 1.6 & 1.5 & 1.3 & 1.1 & 1.3 & 1.5 & 1.5 \\
\hline
\end{tabular}

NoTE. The IP proportion data are estimates of the industries' relative contribution to overall IP growth between the reference year and the following year. For example, a 1 percent increase in durable goods manufacturing between 2000

1 Standard Industrial Classification; see table A.5, note 1 . and 2001 would account for a 0.483 percent increase in total $\mathbb{P}$. 